\title{
"He's on Fire for Justice!": Using Critical Conversations to Explore Sociopolitical Topics in Elementary Classrooms
}

* University of Kentucky, Lexington, Kentucky, USA.

E-mail: laura.darolia@uky.edu

\section{Article Info}

Received: April 17, 2020

Revised: May 13, 2020

Accepted: May 16, 2020

10.46303/jcsr.02.01.3

This is an Open Access article distributed under the terms of the CC BY-NC-ND 4.0 International license.

(https://creativecommons.org/licenses/bync-nd/4.0)

\section{How to cite}

Darolia, L. (2020). “He's on fire for justice!": Using critical conversations to explore sociopolitical topics in elementary classrooms. Journal of Curriculum Studies Research, 2(1), 39-54.

https://doi.org/10.46303/jcsr.02.01.3

\author{
Laura Darolia*
}

\section{ABSTRACT}

Despite the dominant discourse that childhood is a time of innocence, elementary students (kindergarten through fifth grade) notice the world around them, witness and experience injustice and deserve to explore "controversial issues" in their classrooms. This article introduces readers to Olivia and her second grade students. Olivia wanted to create what she called a "social justice classroom" and made intentional curricular moves in order to bring this vision to life. Primarily, she implemented "social justice read aloud time" and read and discussed thoughtfully chosen trade books on "controversial issues" every Friday afternoon. Students were highly engaged in these read alouds and developed understandings and insights well beyond academic content standards. Olivia's approach to teaching aligned with critical literacy, a pedagogical framework that values multiple perspectives, brings sociopolitical topics into the classroom, disrupts the status quo, and moves toward social action and the Inquiry Design Model of social studies education. Using this interdisciplinary lens, empirical examples of the purposeful exploration of "controversial issues" in a second grade classroom are discussed. Through Olivia's voice, along with the voices of her students, description of the learning that happened in this social justice classroom is offered as evidence that teaching controversial issues in elementary classrooms has repercussions far beyond school walls. Implications for both practicing teachers and teacher educators are discussed.

\section{KEYWORDS}

Education; Curriculum studies; Social justice; Controversial issues. 


\section{INTRODUCTION}

We are in the midst of a global pandemic. Coronavirus Disease 2019 (COVID-19) has grabbed the world by the throat, holding hostage the simple motions of going to a place (e.g., office, campus, restaurant, concert, hotel, school, a family member's house) to do a thing (e.g., learn, socialize, eat, make a living, enjoy, embrace). We are in the early days of this crisis and, while much remains unknown, it is clear the effects will be devastating to the global economy, the health care industry, local businesses, and tens of thousands of families who will lose their livelihoods and their loved ones. While there is admittedly very little we can control, in times like these, when much of what we know is rattled and fear is ever-present, we do have choices in how we confront the situation, what we bring to it, and what we make of it.

If the initial wave of the COVID-19 pandemic has revealed anything, it's that the world is small, we are all connected, and we all have a responsibility to care for each other. This is evident through the imperative to socially distance, to check in on elderly neighbors, to patronize local businesses, and to simply be kind and gracious to all as we navigate this new normal together.

Beyond altruistic gestures, however, this moment in history provides unequivocal evidence of the inequities that plague our society. For example, COVID-19 is impacting minority and low-income communities, including Native Americans at alarming rates (Mineo, 2020). Structural inequities that have held Black people in working class jobs while denying them adequate healthcare are exacerbating the effects of COVID-19 on Black communities (Ray, 2020). We look around and realize we are all just trying to survive this pandemic, but is clear the systems we have in place grossly disadvantage certain groups. This provides an opportunity to sharpen our collective focus and efforts around equity and justice. When schools open again and elementary students gather in their classrooms, teachers and children will need to process what just happened, how we responded, and how we will ALL move forward in building a more just society. This creates authentic pedagogical space for critical conversations.

\section{CRITICAL CONVERSATIONS}

Critical conversations can happen when a classroom environment is built around a culture of meaningful talk. In such settings, students learn to listen to and consider multiple perspectives; they feel comfortable trying out new ideas and even changing their minds (Pierce \& Gilles, 2008) Students care about each other, and as a result, they want to hear their friends' thoughts and then feel confident challenging them. During critical conversations, students grapple with big ideas. They critique the world around them, build on each other's thinking, and imagine new possibilities (Pierce \& Gilles, 2008). Through critical conversations, students are able to question why society is organized in the ways it is and engage others in joining them to make change (Pierce \& Gilles, 2008). Ultimately, students make meaning together though discussion. 
Engaging in the meaningful talk of a critical conversation is a crucial skill for children to begin to develop at young ages. While the dominant discourse about childhood is that it is a time of innocence (MacNaughton, 2000), elementary students (kindergarten through fifth grade) notice the world around them, witness and experience injustice, and deserve to explore "controversial issues." These issues can be topics like race and sexuality that elicit strong feelings and ideological stances and often lead to disagreement (Kuby, 2013; Vasquez, 2015). These kinds of issues are laced with unequal power relations and historical oppression and ignite debate about how we should all live together.

If there is ever a time to dig into the idea of how we, on the global, national, state, and local levels should get along, it is once we reunite after a pandemic-driven quarantine. There are many compelling questions to ask, such as:

- What does it mean to be a good citizen?

- Why is it wrong to call Covid-19 the Chinese Virus?

- Who wins/loses during a pandemic?

- What does the Covid-19 response say about America? (C3 Teachers, 2020, pp. 1-4) These questions can be used to stimulate discussion and help students make sense of this moment in history. These particular conversations are yet to be had, as we are living in unprecedented times, but young children deserve to be engaged in critical conversations around issues that impact them.

\section{Children and "Controversial" Issues}

Race and sexuality, power-laden and important sociopolitical topics and often costly aspects of identity, have been explored with young children in elementary schools. Despite the fact that teachers tend to be uncomfortable bringing such topics into the classroom (Bolgatz, 2006), elementary students live with experiences of both, whether explicitly discussed or not. Children as young as three years old are already crafting understandings of race (Lee, Ramsey, \& Sweeney, 2008). Creating space in the classroom to intentionally talk about race strengthens students' critical thinking skills and expands their intellectual capacities (Bolgatz, 2006).

While many teachers choose to adopt the "colorblind stance" in a well-intended effort to prioritize equality, children notice who is different from them, what the differences are, and what those differences mean (Boutte, Robertson, \& Powers-Costello, 2011). When families also adopt this stance, students are left to create their own assumptions and understandings (Darolia, 2019).

Outside of classroom and family dynamics, society remains divided over how to live together within and among our differences. Notably, up until 2019, there had been a steady rise in the number of hate groups in the United States identified by the Southern Poverty Law Center, an organization dedicated to monitoring extremist groups and organizing against hate and bigotry. 
Table 1: Hate Groups in the United States

\begin{tabular}{|l|l|l|}
\hline Hate Groups in the United States monitored by the SPLC \\
\hline Year & Number of hate groups & Change over time \\
\hline 2015 & 892 & \\
\hline 2016 & 917 & +25 \\
\hline 2017 & 954 & +37 \\
\hline 2018 & 1020 & +66 \\
\hline 2019 & 940 & -80 \\
\hline
\end{tabular}

Note: This chart was created with data from the Southern Poverty Law Center at https://www.splcenter.org/hate-map

2018 was a particularly poignant year, as the number of monitored hate groups rose by 66. In the same year, the Federal Bureau of Investigation (FBI) noted an increase in violent hate crimes (Triesman, 2019). While admittedly imperfect data, due to different reporting practices across states, the take away is that people felt empowered within the political climate to use violence against marginalized communities. According to the FBI report, in 2018 hate crimes against Latinx, gay, Asian, disabled, transgender, and Sikh communities increased, while African Americans remained the most frequent targets of racially motivated hate crime.

It does not help that President Donald Trump has voiced little to no opposition to racial hate, notably calling white supremacists at a rally in Charleston, South Carolina "very fine people" (Gray, 2017) and referring to Covid-19 as a "Chinese virus" (Riechmann \& Tang, 2020). This rhetoric stokes xenophobia within our own country, as evidenced by an increase in attacks on Asian Americans (Tavernise \& Oppel Jr., 2020).

Students come from families with varying ideologies. They hear messages at home and absorb messages from different forms of media. Further, young children witness, experience, and think about injustice (Kuby, 2013). Without a space to unpack and make sense of inequity, they are left to manufacture their own understandings. Children need to learn how to analyze sources, use facts and science to make informed decisions and then logically reason them. They need the space to trouble what they know, to listen to different perspectives and to learn to exercise empathy. One way to start them on this journey is to facilitate critical conversations in elementary school classrooms.

\section{Critical Conversations in Elementary Classrooms}

One use of critical conversations in elementary schools is as an avenue for exploring the experiences of marginalized communities. Take for example, using LGTBQ-inclusive curricula to invite elementary students into conversation. Hartman (2018) and Van Horn (2015) engaged in critical conversations with second graders around gender and sexual identity, using children's literature as an entry point. As a result, students came to new understandings about who can 
get married. Blackmon, Darolia, and Oliva (2014) detail how when a first grade class chose to advocate for their male classmate who liked to wear dresses, some parents were proud, while others angrily protested. The school community was rattled, but adults and children bravely engaged in critical conversations about inclusivity. In doing so, many were challenged to consider the often marginalized perspective of a person who does not conform to gender norms. After engaging in this work, the parental complaints quieted and the student continued to proudly wear pink and sparkles.

Parental resistance to engaging young children in critical conversations about sociopolitical topics like gender identity and sexuality is a tangible fear of many teachers (Surette, 2019). Hermann-Wilmarth and Ryan (2019) argue that being confident in the academic reasoning for all curricular decisions and never allowing the resistance of one family to impact the whole class are ways to negotiate parental concerns. Students tend to be interested in sociopolitical issues despite parents' opposition (Darolia, 2019).

Critical conversations can also be spaces for unpacking contentious current events. After the 2016 presidential election in the United States, instead of ignoring the tension in the room, a fifth grade teacher facilitated class discussion around it. Based on observations over time in this justice-oriented teacher's classroom, Payne and Journell (2019) identified three moves elementary teachers can make to effectively guide students through controversial political discussions: 1) maintaining strong and personally affirming relationships; 2) allowing students' the freedom to bring up topics, while using structure to guide discussions; and 3) including current events as valid curricular material. In a similar effort to structure critical conversations, Boutte and Muller (2018) use the dimensions of oppression to gain an understanding of social and political power. In doing so, students can better identify and discuss the themes of 1 ) conquest; 2) divide and rule; 3) manipulation; and 4) cultural invasion found in purposefully chosen read aloud books (Boutte \& Muller, 2018).

What follows is a snapshot of a second grade classroom where students engaged in critical conversations. The teacher, Olivia (all names are pseudonyms) declared she wanted to have a "social justice classroom." Wanting to create a pedagogical space guided by equity and justice, she implemented "social justice read aloud time" where she used purposefully chosen children's literature as entry points to discussion on sociopolitical issues like race and identity. Wanting her curricular materials to be both windows into different perspectives and ways of being and mirrors where students see themselves reflected (Bishop, 1990), Olivia selected high quality picture books to engage her students. Olivia understood the moral and ethical imperative of engaging students in critical conversations around issues that matter to them. I describe how the tenets of critical literacy and the Inquiry Design Model from the College, Career, and Civic Life (C3) Framework for Social Studies (Swan, Lee, \& Grant, 2015) supported her work. 


\section{THEORETICAL FOUNDATION}

This work draws on critical frameworks (Freire, 1970; Vazquez, Janks \& Comber, 2019) that illuminate the social inequities. As Olivia and her students discussed read aloud texts centered on social justice, a critical lens provided insight into students' understandings of power relations and ways to take informed action for the common good.

\section{Critical Literacy}

Critical literacy is a pedagogical framework that considers multiple perspectives, interrupts the status quo, brings sociopolitical topics into the classroom, and moves toward social action (Lewison, Flint, \& van Sluys, 2002). Critical literacy focuses on how texts of all kinds position readers and demands that we consider our sources of information asking questions such as, what is the author's purpose? Why is it like this? Is this fair? Whose voice is missing?

This lens is influenced by Freire, who looked specifically to education as a perpetuator of the status quo. Freire (1970/2000) describes the "banking" model of education as teachers treating students as receptacles into which they deposit knowledge. This classroom approach creates wide boundaries between teacher and student. Freire (1970/2000) believes that when students are confronted with issues that relate to themselves and their worlds, they will be motivated to respond. As such, students must certainly be taught to decode words and images, but must also learn to interpret the social contexts around them (Freire, 1970/2000).

Bringing a critical perspective to teaching means that pedagogical decisions are made in large part based on the resources, passions, and cognitive dissonance of the students in an effort to expose inequities; to examine the relationship between language and power; to understand that texts of all kinds position readers; and to work toward social justice (Vasquez, Janks, \& Comber, 2019). As such, critical literacy is not scripted teaching. Literacy can be understood as a critical social practice, which implies that it is defined by power relations that are unequal and ideological (Luke \& Freebody, 1999). People hold a multitude of literate identities that are shaped by life experiences.

Luke and Freebody (1999) outline the range of practices readers use in their Four Resources Model. The practices are: 1) code breaker (decoding), 2) text participant (comprehension), 3) text user (communication), and 4) text analyst. When analyzing texts, readers consider how those texts are designed to position them in particular ways. This fourth practice aligns with critical literacy. Janks (2010), in her intersecting model of power, access, diversity, and design (2010) discusses the importance of textual redesign. It is not enough to critique texts of all kinds (i.e., books, advertisements, images, social media), students must take the next step to redesign them to be more equitable. In doing so, they resist the pull of apathy and become active agents of change. 


\section{Inquiry Design Model}

These literacy-forward theories work in concert with social studies curricular pathways. The College, Career, and Civic Life (C3) Framework for social studies state standards is rooted in the idea that high quality social studies education is centered on inquiry and prepares students to be informed, critical, and productive members of society (NCSS, 2013). This resource supports states in enriching their social studies standards and is organized into four dimensions: 1 ) developing questions and planning inquiries; 2) applying disciplinary tools and concepts; 3) evaluating sources and using evidence; and 4) communicating conclusions and taking informed action. To bring this framework to life in K-12 classrooms, the Inquiry Design Model (IDM) is a blueprint teacher can use to create social studies inquiries (Swan, Lee \& Grant, 2015). Creating compelling and supporting questions, assigning tasks based on analyzing a variety of sources, and ultimately taking informed action based on what is learned align with critical literacy practices (Janks, 2010; Lewison, Flint, \& van Sluys, 2002; Vasquez, 2004). Using the IDM (Swan, Lee, \& Grant, 2015) and critical literacy as the foundation of this study, these pedagogical frameworks illuminate how to enact the moral and ethical imperative of critical conversations. See Table 2 for a comparison of critical literacy and the IDM.

Table 2: A Comparison of Critical Literacy and the IDM

\begin{tabular}{|c|c|}
\hline $\begin{array}{l}\text { Tenets of Critical Literacy } \\
\text { (Lewison, Flint, \& van Sluys, 2002) }\end{array}$ & $\begin{array}{l}\text { Inquiry Design Model (IDM) } \\
\text { (Swan, Lee, \& Grant, 2015) }\end{array}$ \\
\hline $\begin{array}{l}\text { Welcome sociopolitical issues in the } \\
\text { classroom } \\
\text { - "Can I change it; can I take a different } \\
\text { position on these things; can I look at } \\
\text { the world differently?" (Comber \& } \\
\text { Nixon, 1999, p. 340) }\end{array}$ & $\begin{array}{l}\text { Compelling \& supporting questions } \\
\text { - Intellectually demanding and } \\
\text { personally meaningful drivers of } \\
\text { inquiry }\end{array}$ \\
\hline $\begin{array}{l}\text { Value multiple perspectives } \\
\text { - Open-ended inquiries } \\
\text { - Create counter narratives } \\
\text { - Consider contradictory perspectives }\end{array}$ & $\begin{array}{l}\text { Sources } \\
\text { - Provide content } \\
\text { - Ignite interest } \\
\text { - Expand knowledge } \\
\text { - Offer evidence for arguments }\end{array}$ \\
\hline $\begin{array}{l}\text { Interrupt the status quo } \\
\text { - Analyze how people are positioned } \\
\text { by texts of all kinds (Janks, 2010; } \\
\text { Vazquez, 2004) }\end{array}$ & $\begin{array}{l}\text { Summative and Formative Tasks } \\
\text { - Engage with content and skills to } \\
\text { draft an evidence-based argument }\end{array}$ \\
\hline $\begin{array}{l}\text { Taking action to promote social justice } \\
\text { - Use language to question, critique, } \\
\text { and redesign oppressive practices } \\
\text { - Engage in praxis -reflection and } \\
\text { action - to change the world (Freire, } \\
\text { 1970/2000) }\end{array}$ & $\begin{array}{l}\text { Taking informed action } \\
\text { - Knowledge-based civic engagement }\end{array}$ \\
\hline
\end{tabular}




\section{METHODOLOGY}

Olivia is in the midst of her third year of teaching in a Title 1 school in a midsized, Midwestern U.S. college town. As a Black woman, she remembers being a child who did not see herself reflected in the curricular materials her elementary school teachers used. She is committed to ensuring all of her students-Black, Latinx, mixed race, and white from varying socioeconomic backgrounds-can connect to the stories she reads and the content she teaches. Olivia and I were grade level teammates for one year. When I stepped out of the elementary school classroom and into academia, she welcomed me into her classroom to support her and learn from her teaching.

The data come from a larger case study designed to answer the following research questions: How does a teacher negotiate teaching for social justice within an early childhood classroom? In the midst of this negotiation, what becomes of the teacher's pedagogy? I sought to understand how Olivia moved through or around any challenges that threatened her social justice curricular agenda (i.e., "fitting it in" with the mandated curricula, parent opposition) and also to observe how she brought her social justice classroom to life.

My primary form of involvement with Olivia and her students was to observe and help her think through social justice oriented lessons. From March to mid-June of 2016, I spent one morning and one afternoon in her classroom observing each week. I was a helpful observer (Dyson \& Genishi, 2005) and offered students assistance when needed, but generally stayed quiet and off to the side. Data sources include transcriptions of informal conversations and formal interviews with Olivia, video recordings of social justice read alouds, my field notes, and reflective memos.

During data analysis, I focused on transcripts of social justice read alouds and conversations and interviews I had with Olivia. I coded for moments when talk critiqued social norms. In some instances, this was among students during a read aloud, in others it was Olivia recounting discussions in the classroom to me and reflecting on them. I used Nvivo coding to maintain fidelity to participants' words.

\section{FINDINGS}

The engagement of students in the content and discussion around social justice issues demonstrates how young children hold onto ideas and questions about equity and apply them to their own worlds through critical conversations. Below, you meet Sam, Willow, Andre, and Maya, who did just that. While the excerpts unpacked below are not extended exchanges, they demonstrate meaningful talk: moments when students shared their insights about sociopolitical topics and demonstrated the kind of learning elementary-aged children can do when given the space. 


\section{Sam: "He's on Fire for Justice!"}

After reading books about different races, Olivia chose texts about segregation, including, Separate is Never Equal (Tonatiuh, 2014) and Freedom on the Menu (Weatherford, 2005). These stories introduced the historical context of the civil rights movement to students. Sam, a white child, took issue with the legal separation of races. Olivia explains:

The good thing: if you listen to my Sam... he is so opinionated. He's on fire for justice! The way he says it, 'Who would think that way? I don't understand who decided Black people and white people can't work together. That's just the dumbest thing I've ever heard!' And we read Freedom on the Menu, and at the very end they talked about how Black people weren't allowed to be at the restaurant, but they were cooks. And he said, 'How stupid is that? They can't serve Black people but they can eat the food that they cook?' And I'm thinking, 'Well, yeah! It's just absurd!' and he's like, 'I don't understand it.'

Sam, a white student, experienced strong instances of cognitive dissonance when engaging with texts around race relations. He simply could not make sense of the prejudice and bias that led to the harsh tactics of discrimination. He often raised his hand to vocalize his stance with emphasis and energy. Interacting with the characters and plots of these books produced in him a staunch sense of right and wrong, of what was fair and unfair.

In this instance, Sam is doing the work of both social studies and critical literacy. He's using a source, the read aloud, to build an argument, using language to critique a social norm by responding to the compelling question, "Why is it like this?" Sam spends time and effort in his classroom developing his understandings of equity and justice through reading and discussion. In doing so, he is critically thinking and analyzing social situations - why is it okay to eat food Black people made, but not serve them? He is also building empathy for people treated unjustly. Andre and Willow, who we meet next, transfer their learning to life outside of the classroom.

\section{Andre and Willow: "They Asked Questions Every Single Day"}

Aside from the initial impact of hearing a story, looking at the illustrations, and engaging in discussion, the books about issues of equity Olivia read left a lasting impression on two students in particular. They connected the topics in books to their own lives. At the end of the school year, Olivia reflected on social justice read aloud time and its impact on these two children:

Andre and Willow kind of stick out. It [the lens of equity] just didn't stay with the social justice lesson on Friday... they asked questions every single day. If they were on the playground or they watched something on TV, they would come in and want to talk more about it with the class. I just thought bringing those topics and issues [identity and race] to second graders was so powerful. I think it will be something they will carry with them and continue to wonder about throughout their educational career. 
Andre and Willow internalized plots, characters, and discussions around issues of social justice and developed new lenses through which to view their worlds. Ideas around equity were no longer reserved for social justice lessons, these students honed radars to detect instances of privilege and oppression in their daily lives. Noticing and deliberately bringing social issues into the classroom for discussion prompted them to lead lives that question and critique the way things are. As Olivia said, this was more than a discrete skill, this was a stance, a framework for understanding the world; a way of being that would likely be strengthened and utilized by these students well beyond their second grade year.

When Olivia described exploring sociopolitical issues with her second graders as "powerful," she admitted that creating the space for topics, such as race, to interact with her students and their worldviews had effects. For Sam, the impact came as a resolute sense of right and wrong; for Willow and Andre, it was a heightened awareness. During read aloud discussions, these students considered how they understood and responded to their worlds. This is what Olivia wanted - for her students to internalize a sense of justice, to begin to create a social justice atmosphere where they initiated discussions about equity based on their own experiences.

Sam's desire to strongly question the logic of segregation revealed his developing understanding of race relations. Calling practices of segregation "stupid," he placed judgement upon the sanctioned oppression of Black people. His thinking was equity-oriented as he tried to make sense of how races could be separated at restaurants. His expression of cognitive dissonance was not lost on Olivia. She referred to Sam as "on fire for justice," and admitted she agreed with his thinking. Similarly, Olivia's observation that Andre and Willow questioned social realties every day was evidence that their understandings were also evolving. Both at home and at school, Andre and Willow noticed instances of inequity and they talked about them. Sam, Andre, and Willow were in the midst of creating the "social justice atmosphere" Olivia sought. Watching them revise and recreate their understandings of their worlds with a lens toward equity produced in Olivia an excitement for social justice read aloud time and strengthened her commitment to keep it going. She reflected:

I think they [social justice read alouds] are going really well. As far as just our regular conversations, I think they're [her students] starting to understand that there's a culture of justice, and they may not know how to express it well, but, if things are unfair or things are wrong, they can kind of point it out. I think the conversations we have are helping to give them a deeper understanding of the books that we read. I'm enjoying it. I enjoy the things they have to say.

As Olivia saw glimpses of a "social justice atmosphere" coming to life through critical conversations, she admitted she was having fun. She liked listening to her students' insights and questions and she enjoyed watching that "culture of justice" emerge. This sense of enjoyment 
often accompanies meaningful work. There was one more child in her class, for whom social justice read aloud time was especially significant.

\section{Maya: “...It Helps Kids Identify Who They Are”}

While Sam, Andre, and Willow expanded their understandings of the world, for one student in particular, the read alouds and discussions around race had a momentous personal impact. Maya is a biracial child. Her biological father is Black and her mother is white. At the time of this study, Maya had never met or seen her biological father and only knew her white step-father as her dad. She had white siblings and her family never explicitly discussed or identified her racial background with her. As a result, Maya was confused about her appearance. Before attending this school, she was in a more rural part of the state and as the only person of color in her class, was subjected to ridicule.

Moving to a new school and into Olivia's classroom with white, mixed race, and Black students was an initial step for Maya coming to understand her racial identity. Olivia's curricular decisions to include read alouds and critical conversations gave Maya permission to acknowledge her confusion. Happy to be Nappy (hooks, 1999) was particularly influential, as a classmate referred back to this read aloud to help build Maya's confidence about her appearance. At the end of the school year, Olivia reflected on teaching for social justice and the impact critical conversations had on Maya:

Laura: What do you think they [the students] are leaving with after this year where you did all these kinds of [social justice] lessons?

Olivia: I think the more impactful ones ... [were] conversations about poverty and race. And I think they were able to look at each other differently. The incident that happened with Maya and just having her coming to her own consciousness about who she is and what she looks like and the students helping her identify with, 'Your hair is this type of way so it's a strong possibility that you're Black or biracial.' They did it so respectfully.

Laura: You had that conversation?

Olivia: Yeah. And then...Jordan [a student] said, 'You can be proud of your hair just like in our story [Happy to be Nappy].' And so they're kids, they'll talk about each other, but they know now that certain things are not okay and how to advocate for one another, and so hopefully they don't forget those things.

Laura: So did they help Maya identify with her race?

Olivia: I think so. At the end of the school year I think she still had her issues. But I feel like she was a totally different kid from the beginning of the year, just not knowing who she was, now knowing she was biracial. I think it even helped her mom. She was able to go home and have a conversation with her mom about it. Her mom felt it was powerful. She felt pretty good at the end of the school year... I think that just goes to show you how 
important those conversations [about race] are because it helps kids identify who they are.

For Maya, reading books aloud about race and identity provided an entry point to explore her own. Because Olivia cultivated an environment of meaningful talk where it was okay to share insights and questions about such things openly and honestly, Maya's classmates were able to help her think through the uncertainty she had about her hair and her skin color. As Olivia mentioned, this not only positively impacted Maya, but also Maya's family who admittedly struggled with how to address Maya's racial identity with her. The books Olivia read provided an entry point to discussion; Maya and her mom were able to talk about her racial identity for the first time.

\section{DISCUSSION}

Olivia used social justice read aloud time to engage in critical conversations about race and identity, asking compelling questions such as, "Why is it like this?" Olivia purposefully welcomed controversial topics into her classroom and facilitated discussions that led students to challenge the commonplace and make meaning together. Students' learning was personally relevant as they actively developed lenses for equity and came to new realizations about themselves and the world around them. Both in-service teachers and teacher educators can learn from Olivia and her students.

\section{Implications for In-Service Teachers and Teacher Educators}

Olivia's experiences, including her childhood memories, influenced her teaching. Her personal interest in current events, specifically around race relations, guided her lesson planning. Through the read alouds she chose, she welcomed topics like segregation and identity into the classroom, making them worthy of discussion. She asked questions that elicited silenced perspectives and imagined more equitable social spaces. Her pedagogy transcended a scripted teacher guide. Olivia was resolute that the purpose of school is to provide the space for her students to explore the topics that matter to them, to question how things are, and to consider multiple perspectives. She believed that this, more than following a guide, was truly teaching.

Teaching is necessarily political. The decisions we make, the topics we choose to prioritize, the books we choose to read position students in particular ways and that must be acknowledged (Kelly \& Brookes, 2009). We teach who we are and that matters. First and foremost, in order to facilitate critical conversations, teachers of any age group must scrutinize their own beliefs and biases and reflect on how they either covertly or overtly appear during instruction and interactions with students and families.

Like Olivia, teachers must also confidently identify their purpose as educators. What kinds of experiences should students have? What academic, social, and emotional priorities should guide the work completed during school year? What role do critical conversations have in an 
elementary school classroom? This will influence a teacher's ability to better support the investigation of sociopolitical topics with students. This intensely personal work requires time, commitment, and a willingness to lean into discomfort.

\section{Meaningful Talk}

Creating a classroom environment where talk is meaningful is key. Olivia did this by building relationships with students, respecting their identities, and validating students' experiences, insights, and questions. She also explicitly taught her students how to participate in group discussions. Teaching the skills of engagement, how to listen to learn and how to respectfully disagree with or challenge a classmate's stance are crucial skills for both children and adults to hone. Practicing how to enact these moves or observing and debriefing on high quality discussions are ways to introduce students to meaningful talk. Further, teachers and students can co-create a list of "talk norms" that everyone signs to solidify their commitments. Once this culture of talk is created, the classroom space is better suited for critical conversations.

Both elementary and teacher preparation spaces should be built around the tenets of critical literacy (Lewison, Flint, \& van Sluys, 2002) and the IDM (Swan, Grant, \& Lee, 2015). Engage students in topics that matter to them, including those deemed "controversial." Use current events as valid curricular material and ask compelling questions. Provide sources for students to analyze and teach them how to build reasoned arguments. Prioritize justice and have students work to take action by redesigning texts in more equitable ways. When teacher educators structure methods classes accordingly, pre-service teachers get to experience what it feels like to learn in this way, potentially leading them to replicate the experience with their future students.

\section{We Need our Students to be Justice-Oriented}

Combining the tenets of critical literacy (Lewison, Flint, \& van Sluys, 2002) with the IDM (Swan, Grant, \& Lee, 2015) creates opportunities for teachers to use their own expertise to create standards-based, engaging, relevant, and rigorous inquiries. Inquiries that will invite students even in elementary school - to critique, analyze, and question the ways things are. Students will scrutinize primary and secondary sources in order to create new understandings, take action and redesign their worlds in ways that prioritize the common good. Like Sam, who is "on fire for justice" or Andre and Willow who have new lenses through which they see the world, we need the next generation to be able to consider multiple perspectives, to understand inequity, and to reason logically and strategically to make things better. Critical conversations around topics that matter allow them to learn these skills.

Looking around our world in the spring of 2020, Covid-19 is disproportionately ravaging minority communities (hate groups are active, Democrats and Republicans are sharply divided 
(Newport, 2019), and civil discourse is a rarity. We need a generation of people who can actively work to understand multiple perspectives and then take informed action to redesign the inequity and strife in which we are currently seeped. Olivia reminds us that school is the place to do this work. She reflects:

[...] you have the issues [of equity] outside of the classroom that are never addressed in the classroom and I think the classroom is the most important place to talk about these things because you go home and families have opinions and students don't get to discuss it. There is no dialogue. No dissecting of what's happening. It's just what you see in the news. What do you do with that information? I imagine for some kids it so frustrating to want to talk about these things and not have a space to learn about them.

Let's commit to engaging in personal reflection so we can effectively facilitate critical conversations in our educational spaces. When can be together in the same rooms again, let's not forget what it felt like to be forced apart. We can now narrow our focus on our shared humanity. Our collective efforts can combine to create a new normal that prioritizes critical thinking, multiple perspectives, analysis, and informed action. These efforts should include children and they can begin in kindergarten classrooms with critical conversations.

\section{REFERENCES}

Blackmon, L., Darolia, L. H., \& Oliva, J. (2014). Pink sparkly shoes: A transformed community, a transformed curriculum: Perspectives from three voices. In Felderman, C.B., Kissel, B., and Nash, K.T. (Eds.) Perspectives and provocations in early childhood Education.

Volume 3. Information Age Processing.

Bishop, R. S. (1990). Mirrors, windows, and sliding glass doors. Perspectives, 6(3), ix-xi.

Bolgatz, J. (2006). Revolutionary talk: Elementary teacher and students discuss race in a social studies class. The Social Studies. Nov/Dec, 259-264.

Boutte, G. S., Lopez-Robertson, J., \& Powers-Costello, E. (2011). Moving beyond colorblindness in early childhood classrooms. Early Childhood Education Journal, 335-342.

Boutte, G. S. \& Muller, M. (2018). Engaging children in conversations about oppression using children's literature. Talking Points, 30(1), 2-9.

Comber, B. \& Nixon, H. (1999). Literacy education as a site for social justice: What do our practices do? In Edelsky, C. (Ed.), Making justice our project: Teachers working toward whole language practice (316-351). Urbana, IL: National Council of Teachers of English.

Darolia, L. H. (2019). "Where are the core values of reading, writing, and math?" An elementary school teacher navigates parental opposition to her "social justice classroom." Perspectives and Provocations in Early Childhood Education, 8(4). https://www.earlychildhoodeducationassembly.com/uploads/1/6/6/2/16621498/4.Aut hor.pdf 
Dyson, A. H. \& Genishi, C. (2005). On the case: Approaches to language and literacy research. New York, NY: Teachers College Press.

Freire, P. (1970/2000). Pedagogy of the oppressed, 30th anniversary ed. New York, NY: Continuum International Publishing Group.

Gray, R. (2017, August 15). Trump defends white-nationalist protestors: 'Some very fine people on both sides'. The Atlantic.

https://www.theatlantic.com/politics/archive/2017/08/trump-defends-whitenationalist-protesters-some-very-fine-people-on-both-sides/537012

Hermann-Wilmarth, J. M. \& Ryan, C. L. (2019). Navigating parental resistance: Learning from responses of LGBTQ-inclusive elementary school teachers. Theory into Practice, 58(1), 89-98.

hooks, b. (1999). Happy to be nappy. New York, NY: Disney-Hyperion.

Janks, H. (2010). Literacy and power. New York, NY: Routledge.

Kelly, D. M. \& Brooks, M. (2009). How Young is Too Young? Exploring Beginning Teachers' Assumptions about Young Children and Teaching for Social Justice. Equity \& Excellence in Education, 42(2), 202-216

Kuby, C. R. (2013). Critical literacy in the early childhood classroom: Unpacking histories, unlearning privilege. New York, NY: Teachers College Press.

Lee, R., Ramsey, P.G., \& Sweeney, B. (2008). Engaging young children in activities and conversations about race and social class. Young Children, 63(6), 68-76.

Lewison, M., Flint, A.S., \& van Sluys, K. (2002). Taking on critical literacy: The journey of newcomers and novices. Language Arts, 79(5), 382-392.

Luke, A., \& Freebody, P. (1999). Further notes on the four resources model. Reading Online. Retrieved May 5, 2015, from www.readingonline.org/research/lukefreebody.html MacNaughton, G. (2000). Rethinking gender in early childhood education. Thousand Oaks, CA: SAGE.

Mineo, L. (2020, May 8). For Native Americans, COVID-19 is the 'worst of both worlds' at the same time'. The Harvard Gazette.

https://news.harvard.edu/gazette/story/2020/05/the-impact-of-covid-19-on-nativeamerican-communities/

National Council for the Social Studies. (2013). The College, Career, and Civic Life (C3)

Framework for Social Studies State Standards: Guidance for Enhancing the Rigor of K-12 Civics, Economics, Geography, and History. Silver Spring, MD: NCSS.

Newport, F. (2019, December 5). The impact of increased political polarization. Gallup. https://news.gallup.com/opinion/polling-matters/268982/impact-increased-politicalpolarization.aspx 
Payne, K. A. \& Journell, W. (2019). "We have those kinds of conversations here...": Addressing contentious politics with elementary students. Teaching and Teacher Education, 79, 7382.

Pierce, K. M. \& Gilles, C. (2008). From exploratory talk to critical conversations (37-53). In Mercer, N. and Hodgkinson, S. (Eds.) Exploring talk in school: Inspired by the work of Douglas Barnes. Thousand Oaks, CA: SAGE.

Ray, R. (2020, April 9). Why are Blacks dying at higher rates from COVID-19?. Brookings. https://www.brookings.edu/blog/fixgov/2020/04/09/why-are-blacks-dying-at-higherrates-from-covid-19/

Riechmann, D. \& Tang, T. (2020, March 18). Trump dubs COVID-19 'Chinese virus' despite hate crime risks. U.S. News and World Report. https://www.usnews.com/news/healthnews/articles/2020-03-18/trump-dubs-covid-19-chinese-virus-despite-hate-crime-risks

Surette, T. (2019). Too scared to teach: Secondary students' insights into educators silencing and stigmatizing gender and sexual diversity in public schools in Alberta, Canada. Journal of Contemporary Issues in Education, 14(2), 33-49.

Swan, K., Lee, J., \& Grant, S. G. (2015). The New York state toolkit and the Inquiry Design Model: Anatomy of an inquiry. Social Education, 79(5), 316-322.

Tavernise, S. \& Opell Jr., R. A. (2020, March 23). Spit on, yelled at, attacked: ChineseAmericans fear for their safety. The New York Times. https://www.nytimes.com/2020/03/23/us/chinese-coronavirus-racist-attacks.html Tonatiuh, D. (2014). Separate is never equal. New York, NY: Henry D. Abrams.

Treisman, R. (2019, November 12). FBI reports dip in hate crimes but rise in violence. National Public Radio. https://www.npr.org/2019/11/12/778542614/fbi-reports-dip-in-hatecrimes-but-rise-in-violence

Van Horn, S. E., \& Hawkman, A. M. (2018). First comes love, then comes marriage (equality): Welcoming diverse families in the elementary classroom. Social Studies and the Young Learner, 31(2), 24-32.

Vasquez, V. (2004). Negotiating critical literacies with young children. New York: Routledge. Vasquez, V. (2015). Using the everyday to engage in critical literacy with young children. In K. Winograd (Ed). Critical literacies and young learners: Connecting classroom practice to the common core. New York, NY: Routledge.

Vasquez, V., Janks, H., \& Comber, B. (2019). Critical literacy as a way of being and doing. Language Arts, 96(5), 300-311.

Weatherford, C. B. \& Lagarrigue, J. (2005). Freedom on the menu: The Greensboro sit-ins. New York, NY: Penguin Group 